\title{
Communication Strategies in Classroom Discussion of Graduate Students
}

\author{
Fadilla Taslim ${ }^{1}$, Hervina $^{2}$ \\ ${ }^{1}$ English lecturer of STKIP Yayasan Abdi Pendidik.an, fadft.1203@gmail.com \\ ${ }^{2}$ English lecturer of STKIP Yayasan Abdi Pendidikan, vina bz03@yahoo.com \\ (c) (i) (2) \\ (C)2021 by the authors. Submitted for possible open access publication under the terms and conditions of the Creative Commons \\ Attribution-ShareAlike 4.0 International License-(CC-BY-SA) (https://creativecommons.org/licenses/by-sa/4.0/) \\ d.) DOI : https://10.30983/mj.v1i1.5126 \\ \begin{tabular}{l|l|l} 
Submission: March 21, 2021 & Revised: June 02, 2021 & Published: June 30, 2021
\end{tabular}
}

\begin{abstract}
Abstrak
Dalam berkomunikasi diperlukan beberapa strategi agar komunikasi tersebut dapat berjalan sesuai dengan yang diinginkan. Strategi tersebut dilakukan ketika si pembicara menemukan kesulitan dalam kosakata terutama ketika mereka berbicara bukan dalam bahasa asli mereka. Penelitian ini bertujuan untuk mengidentifikasi strategi komunikasi yang di pakai oleh mahasiwa Pasca UNP ketika mereka bertanya dan menjawab pertanyaan selama diskusi kelas dan juga mengekplorasi alasan dalam memakai strategi tersebut. Tiga kelas di pilih sebagai subjek. penelitian dengan menggunakan teknik, purposive sampling. Data diambil dari pengamatan kelas dan wawancara. Dari hasil pengamatan dan wawancara inilah diketahui bahwa Mahasiswa Pasca UNP Program Studi Bahasa Inggris dalam menjawab dan bertanya mengunakan semua jenis Strategi komunikasi. Namun strategi yang paling banyak diaplikasikan mahasiswa baik ketika mempresentasikan dan ketika bertanya adalah strategi stalling dan time gaining - filler dan gambits yang digunakan untuk mengambil kesempatan untuk berfikir sejenak dalam melanjutkan kalimat berikutnya. Pada umumnya baik dari pihak pemakalah dan penanya dalam menggunakan strategi komunikasi tersebut beralasan untuk menjaga komunikasi tetap berjalan lancar, berusahan untuk membuat pembicaraan lebih jelas dan untuk. mengurangi kegugupan dan kecemasan.
\end{abstract}

Kata Kunci: Strategi Komunikasi, Tanya Jawab, Diskusi Kelas

\begin{abstract}
In communicating, several strategies are needed so that the communication can run as desired. The strategy is carried out when the speaker finds difficulties in vocabulary especially when they speak not in their native language. This study aims to identify the communication strategies used by Post-UNP students when they ask and answer questions during class discussions and also explore the reasons for using these strategies. Three classes were selected as research subjects using purposive sampling technique. Data were taken from class observations and interviews. From the results of these observations and interviews, it is known that Post-UNP Students of the English Study Program in answering and asking questions use all types of communication strategies. However, the strategies that are mostly applied by students both when presenting and when asking are stalling and time gaining strategies -filler and gambits- which are used to take the opportunity to think for a moment in continuing the next sentence. In general, both the presenter and the questioner use this communication strategy for reasons to keep the communication going smoothly, trying to make the conversation clearer and to reduce nervousness and anxiety.
\end{abstract}

Keywords: Communication Strategies, Question and Answer, Classroom Discussion

\section{Introduction}

Communication is the basis of human interactions and language is a tool of those interactions. By using language, people communicate each other on/about what they feel or think. In communicating, a speaker tries to convey certain message to her/his listener. Communication naturally is a symbolic process whereby meaning is shared and negotiated ${ }^{1}$. As defined by Turney (cited in Marsh 1992:34), communication is" as the sharing of the message or attitudes that produces the degree of understanding between a sender and a receiver". It means that, in communicating, a speaker and a listener are giving and receiving information each other.

1 Irwandi Irwandi, Albert Albert, and Nur Azmi Alwi, 'Building Teachers' Intercultural Communication Competence in the Digital Era', Proceeding IAIN Batusangkar, 3.1 (2019), 179-82 <http://ecampus.iainbatusangkar.ac.id/ojs/index.php/proceedings/article/view/1304>. 
To get the information, they should build an understanding of the utterances emerged between them. As they can achieve this, they can get what they want to express succesfully. In other words, communication will run smoothly when the speaker and the listener can catch the message that the speaker wants to tell. Yet, in speaking, this often may not run smoothly, especially when the speaker and the listener try to speak in the foreign language. Therefore, sometimes the speaker and the listener commit certain efforts to make the communication runs well. This effort is called communication strategies.

The term communication strategy has been defined in several ways. Some experts defined Communication strategies as the way of someone utilizes to deal with problems and difficulties in spoken communication. These problems probably due to lack of linguistic knowledge or lack of contain knowledge related to certain topics.

From those quotations, it can be seen that the communication strategies are the attempts made by a speaker to get rid of his/her problem in expresing message. It says that when a speaker, a learner, finds himself in difficulty to communicate in a foreign language because of his linguistic limitation, he will try to make some attempts to make the communication runs effortlessly. Therefore, communication strategies are applied as the devices to deal with the difficulties and the breakdowns in communication. For example, the learner may use verbal and non verbal strategies such as explanation, paraphase, mime or even gesture to help him/her to express thoughts/feelings.

Celce-Murcia, Dornyei \& Thurrell (1995:28) categorized five communication strategies in general ${ }^{2}$. Firstly, avoidance \& reduction Strategies. This strategy is classified into into subcategory. They are mesage abandonment - the speaker begins to talk about a concept but is unable to continue and leaves a message unfinished because of language difficulties; topic Avoidance - The speaker avoids talking about the topic areas or concepts which pose language difficulties; message Replacement - takes the related concepts which may presuppose the desired content.

Second, Achievement or Compensatory Strategy. This strategy consist of eight subcategories ; Non Linguistics means or Paralinguistics Strategies - the speaker tries to use nonlinguistics; literal translation - the speaker translates literally a lexical item, an idiom, a compound word, or structure from a native language to a target language; borrowing or code switching strategy - the speaker switches from a target language to the native language words; foreignizing - the speaker uses a native language words or phrase by adjusting it to a target language phonologically; approximation - the speaker uses a target language word which shares enough semantics features in common with the desired lexical item; word coinage - the speaker makes up a non existing target language word on the basis of a supported rule; Circumlocution the speaker describes or exemplifies the object or action instead of using the appropriate target language item or structure; the use of all purpose words or smurfing e.g the overuse of thing, stuff, gadget, what do you call it; retrieval- the speaker repeat the words, e.g. bro...bron.....bronze.

Next, Stalling or Time Gaining Strategies also consist of two subcategories; filler /hesitation devices- filling words or gambits to fill a pause and to gain time to think e.g well, actually, allight; self repair or restructuring- the speaker sets up a new speech when the original one fails.

${ }^{2}$ Celce-Murcia et.al. (1995). Communicative Competence: A Pedagogically Motivated Model With Content Specifications. Issues in Applied Linguistics. Vol 6 no 2. ISSN 1050-4273. 5-35 
Then, Self Monitoring Strategies make up of Self Initiated Repair techniques - to correct her/his own word e.g I mean...; Paraphrasing (over-elaboration)- restate the word into a simple form of vocabulary e.g. This is for students ....pupils ...when you're at school.

Finally, Interactional Strategies consist of two techniques; appeals for assistance-the speaker turns to the interlocutor for help; meaning Negotiation Strategies- the speaker shows an indicators of non/miss-understanding like request, expression of non-understanding or comprehension checks. For example, the speaker does the comprehension checks whether the hearer can follow the speaker by saying, Am $i$ making sense? or whether the hearer is listening such as Are you still here? or Do you listen to me?

Communication commonly occured in the form of question and answer because they are two important elements in building up the interactions. Without these elements, communication will seem monotonous. Question is the skill of forming and using questions appropriately to elicit information while answer implies the satisfying of the question, demand, call or need.

More over, Richard and Smith (2002) define question as an utterance that is addressed to a listener or reader and asks for an expression of fact, opinion and belief ${ }^{3}$. In the daily life, Question and answer commonly often occur respectively. When one asks a question, it will be responded by another by giving an answer.

Related to how the English learners of Indonesia construct questions and answers, there are some difficulties found. Firstly, the differences between English and Indonesian's grammar, such as in the inversion and time markers (Zaim, 1997: 3), make questions or answers cannot be constructed right a way ${ }^{4}$. This probably occurs because a speaker tends to translate sentences from Indonesian to English first before utterring some questions or giving the answers. Moreover, the speaker is also confused with the use of WH-questions and Yes/No questions because of the interference of the Indonesian. Here, the speaker tends to put the wrong choices of the question forms. For instance, the question that is supposed to be in WH-question form will be applied in the Yes/No question form, or vice versa. The next reason is the lack of vocabulary, that makes speaker fells reluctant to ask question or give aswer.

Then, in the higher education, university level, classroom discussion is usually applied in the teaching learning process. This is because classroom discussion can facilitate the learners to explain the ideas or to present the opinion. As Arends (2012:431) states that classroom discussion can achieve al least three goals ${ }^{5}$. First, discussion enhances the students thingking and assists them in constructing their comprehension of academic content. This will helps students to strengthen and extend their knowledge of the topic and increase their ability to think about it. Second, discussion promote students involvement and engagement which makes the students takes responsibility for their learning and not depend solely on the teacher. Third, discussion is used by the teacher to help students learn important communication skill and thingking process.

There are three stages of class discussion namely: pre-discussion, discussion and postdiscussion. Pre-discussion is presentation session, two or three presenters explain material of a given topic. Next stage is discussion. In discussion session ,usually, there are two substages in discussion. They are asking suggestion and comment from the participant of discussion and

3 Richard, Jack C and Richard Smith. (2002). Longman Dictionary of Language Teaching and Applied Linguitics. London: Longman.

4 Zaim, Muhammad. (1997). The Acqusition of Questions by Indonesia Adult Learners of English as A Foreign Language. University of Tasmania. Unpublished Disertation.

5 Arends, Richard I.(2012). Learning to Teach (9ed). New York: McGraw Hill. 
discussing the topic with the audience. The last stage is post-discussion. In this stage, there is a peer feedback from the observer or the evaluator. This stage is needed to straigthen the topic that beyond of the discussion. Also, it helps the participant of discussion to get conclusion of their discussion.

This kind of technique is used also frequently in The State Unversity of Padang, especially for the Graduate Program students. The state university of Padang was chosen as the site of the research since this unveristy is the only University that has english education major for graduate students in west sumatera. The graduate English students were the participants regarding to their english proficiency level were intermediate level (the average TOEFL score was 453))

In this University especially for English Education Major, Classroom discussion was mostly employed in learning teaching process. Regularly, The classroom discussion was scheduled for one topic every week. Eventhough It was mediated by the lecturer, the athmosphere of the discussion seems to be semi serious condition.

Lots of research had been conducted in this fields such as inverstigating communication strategies in language acquisition (Kalisa, 2019), she analyzed communication strategies by using language of instruction. While Yusparizal et.el (2018) conducted the reseach on the use of communication strategies by ELT students acros the gender. The communication strategies used by male and female students were in the same amount, 10 of 12 strategies. Then, Abunawas (2012), Pangaribuan et.al (2020) investigated the use of communication strategies on teachers. They discovered that most used strategies in communication were code switching to overcome the barriers between the teacher and the students. Almost similar to the writer's research, Permana et.al(2019) conducted the research on Communication strategies in speaking for presentation. They sought for the types of strategies used by the students in presentation.

Aliakbari and Allvar (2009) conducted the research about the communication strategies in the written medium : the effect of language proficiency. They studied the communication strategies by using written medium. More over, he compared the result of the communication strategies in written media between the higher level of proficeincy and the lower one. He came to conclusion that the higher level of proficiency student used significantly more reconceptualization strategies than the other group with a lower level of language proficiency.

Former studies conducted the research mostly in the oral arranged talk environtment (Permana, 2019; Kalisa, 2019; Yusparizal 2018) . Therefore, in this study, the writer identifed the communication strategies employed by the students in their natural setting of talk, namely, classroom discussion which focused on asking question (audiences), and answering question (presenters) and the reasons of using those strategies in classroom discussion of graduate program State University of Padang.

\section{Method}

The research is classified into descriptive research which mixes quantitative and qualitative method. The research was carried out in Graduate Program of the State University of Padang. The participants of the reasearch were the second year students of Graduate Program. Because the focus of this research are questions and answers, the writer solely focused on the students giving some questions, the audience, and the students delivering the answers, the presenter, who apply communication strategies in class dicussions.

The writer gathered the data from the class discussions by recording the utterances used during the discussions. It was helped by a handy camera and recorder. She recorded the interactions by using handy camera and used recorder for the interviews. She also interviewed the 
presenters and the audiences who employed the comunication strategies to seek the reasons of using the strategies

The data analysis for this study were conducted qualitatively and quantitatively. In qualitative analysis, the writer applied the procedures suggested by Miles and Huberman (1992: 20). They proposed that, in qualitative research, the writer analyzed the qualitative data interactively and continously in every step of research untill the data were saturated by doing a set of activities. They are data reduction, data display and verification or conclusion. Frequency of data were identified

\section{Findings and Discussion}

\section{Communication Strategies Employed by the Students in Asking Question}

The researcher found that communication strategies frequently employed by the students in asking question is Stalling and time gaining Strategy. It can be seen in the table belows, Table 1: The Distribution Frequency of Communication Strategies employed by the students asking question

\begin{tabular}{|clll|}
\hline No & Communication Strategies & Frequency & Percentage \\
\hline 1 & Avoidance and Reduction & 1 & $1 \%$ \\
\hline 2 & Achievement and Compensatory & 73 & $29 \%$ \\
\hline 3 & Stalling and Time Gaining & 163 & $65 \%$ \\
\hline 4 & Self Monitoring & 2 & $1 \%$ \\
\hline 5 & Interactional & 11 & $4 \%$ \\
\hline Total & & $\mathbf{2 5 0}$ & $\mathbf{1 0 0} \%$ \\
\hline
\end{tabular}

Here, the most frequent strategy employed by the students in answering question is stalling and time gaining strategy occured 163 times (65\%). Then, the least frequent strategy perceived by the students is avoidance and reduction strategy. This strategy was employed by the students in asking question only once or only $1 \%$ category.

The students in asking question, audiences, frequently used stalling and time gaining strategy which contains two sub-categories, namely, Filler or Gambit and Self Repair or Restructuring. Here, the students employed only 128 times of fillers or gambit (79\%) and 35 times of Self Repair or Restructuring (21\%).

They used fillers or gambit as one of sub-category of stalling \& time gaining strategy. For example,

(1) OK...

(2) Ya...

(3) ... mm.. It is about grading up the test specification

(4) as it is stated in the book and also explained by our friend. ....... There are some weaknesse

In this case, the audiences uttered as it showed in data (1), (2) and the beginning of data (3) and (4) . they utilized filler and gambits. Fillers like ok...mm...or a.....was helping them to take time to think of the following sentences that would be uttered. Gambits as in data (4) assisted them to recalled what had been discused and gave them time to look for the suitable word in the target language otherwise they couldnot arrange a good sentence as they intended to. So that, the others understood with what they asked. Meanwhile, gambits were used by the audience also for 
giving introduction before giving their question and sometimes also for giving clarification of the question. Meanwhile, for self repair and restructuring the audience employed this strategy when they faced the difficulty in arranging the question to be given. They restructured the sentence when they found that what the question intended to wasnot suitable with what they produced while speaking. So, the execution plan is not in line with their concept plan.

For the second strategy frequently employed by audiences is achievement and compensatory strategies. It was found that audiences mostly applied literal translation. The following is the example of this strategy

(5) Aaaa.. My question next is how could

(6) I think when..it is explained I think it is better the presenter to give example to make it clear! Thank you.

In data (5) it showed that the audience translated literally form L1 to L2 which was supposed to be My next question instead of MY question next and so did the data (6). It would sound Naturally if she uttered some examples should be given to make it clear since the emphasis was giving example The audiences employed literal translation because they probably wanted the presenters understood with their questions. As it stated before, L1 will influence when the speaker speaks in L2 (Selinker in Ellis, 1985:46) because as the principle process operated in interlanguage, he states that it is one way for the speaker to internalize the target language and to reduce the learning burden ${ }^{6}$. Then, borrowing or code switching seldom occured for the audience. The audience applied borrowing or code switching probably because they have no idea about the next utterance in the target language or probably they were afraid of missunderstanding.

In the other case such as retrieval, the audiences just employed retrieval for fixing their pronunciation such as diad...disadvantage or the stat...the standardized test. they did this probably because they were indoubted with the pronunciation of the terms. That's why they did repetition in expressing the terms.

Word coinage, non linguistics means and circumlocution are seldom found in the class discussion audiences. Probably, their capability in using L2 have been regarded as good. Therefore, the use of word coinage rarely appeared since their vocabulary have been enough for creating at least such a simple statement. Meanwhile, for non linguistics is similar to the presenters, they tended to use this strategy because they just wanted to reduce the nervousness. Then, for circumlocution, it was discovered that they rarely used this because they prefered using paraphrase to circumlocution.

In addition, there are 4 subcategories of achivement and compensatory werenot obtained in the class discussion. They are smurfing, circumlocution, approximation, and foreignizing. This phenomena probably came about as the audiences arenot the persons in charge who give more explanation. Also, they only asked for the question that it only limited time for them to apply those strategies.

In interactional strategy, the sub-category of Meaning negotiation used only to emphasize the audiences' questions.

(7) something that comes in my mind is how could we meet this two points that are very contrast, right?

\footnotetext{
${ }^{6}$ Ellis, Rod.(1985). Understanding Second Language Acquisition. Oxford: Oxfrod University Press.
} 
In this cases, they utilized it to make them sure with their utterances by confirming to their partners. For the other sub-categories, appeal for assistance occured in the class discussion by saying a statement like what is it? what we call it? This utterances were used to ask the others about the appropriate words or terms. Yet, it also seem that the use of meaning negotiation was not for asking help. The same case as in the presenters, this phenomenon also occured in the audience side like the use of the expression what we call it? this utterance cannot be regarded as a question to ask for a favour, but it will closely related to just like asking herself or himself about the choice of word that he or she intended.

\section{Communication Strategies Employed by the Students in Answering Question}

Communication strategy employed by students who answered the question in class discussion is also Stalling and time gaining strategy. It also can be seen from the following table, Table 2: The Frequency of Communication Strategies employed by Students in Answering Question (presenters)

\begin{tabular}{|clcc|}
\hline No & Communication Strategies & Frequency & Percentage \\
\hline 1 & Avoidance and Reduction & 20 & $5 \%$ \\
\hline 2 & Achievement and Compensatory & 158 & $34 \%$ \\
\hline 3 & Stalling and Time Gaining & 263 & $55 \%$ \\
\hline 4 & Self Monitoring & 5 & $1 \%$ \\
\hline 5 & Interactional & 22 & $5 \%$ \\
\hline & Total & $\mathbf{4 6 7}$ & $\mathbf{1 0 0} \%$ \\
\hline
\end{tabular}

The most frequent strategy employed by the students in answering question is stalling and time gaining strategy which occured 263 times (55\%). Then, the least frequent strategy perceived by the students is self monitoring. This strategy was employed only 5 times or only $1 \%$ from each categories.

The students giving the answer, presenters employed the communication strategies that is commonly used during the discussion is also stalling and time gaining strategy. This strategy is divided into two sub categories. They are filler/gambit and self repair or restructuring.

It is found that the most sub-category strategy employed by the speaker is using filler/gambit. Fillers were used when the speaker took some times to think for her/his next sentences. Also, probably, because presenters as the person who has responsible to the topic discussed, they did their best efforts in giving the explanation. Therefore, they have to be ready for the question given by the audience. This probably made them become more careful in arranging the sentence.

The examples of the students strategy in fillers or gambit seen below,

(8) Ooo..OK.. mmm. What we know before is there is a changing of the student's final score that what $\mathbf{I}$ know that is kkm...

(9) OK. For that one, we have to know What's the purpose for that action? Why the teacher?

Here, the presenters employed various gambits or fillers in taking time to think. beside using fillers like aaa the presenter also used the introductory conversation or gambit as what we know before, what $i$ know, and for that one we have to know for starting her explanation .

Then, gambit is commonly used by the presenters as semantic introducer. As it is stated by Keller (in Richard, 1982:19) that gambit has function as semantics introducer that is to indicate the general frame of the topic during the talk. Mostly they started their explanations by using 
gambit'. It seems that they also used gambit not only as an introduction of their statement but also as taking time to think. As a result, it can be seen that they used stalling \& time gaining about 263 times (filler/gambit) occured 205 times and self repair $\&$ restructuring 58 times.

For the next strategy frequently employed by presenters is achievement and compensatory strategies. It was found that presenters mostly applied literal translation. The example can be seen as follows,

(10) OK ........a to save the time ,I will go to the second question, first that's about why is multiple choice

Since presenters had a high encouragement to give explanation to the audience, they unconciously applied literal translation. This strategy was employed by them just to make the information ran smoothly. Therefore, the listeners could get the point of information about what they had explained

Literal translation is a part of language interference. Therefore when non native speaker speaks a target language, his or her language will be influenced by his or her native language. This phenomena is mentioned as the principle process operated in interlanguage. He states that it is one way for the speaker to internalize the target language and to reduce the learning burden.

Literal translation simultanously used in gambit when the presenters began his/her explanation. As stated previously, literal translation occurs because of the influence of the native language such as the utterances employed by the presenters and audiences, that's why I say that, I think like this, I think that. Besides, literal translation also occured in the diction such as the utterance, ok we stop the question first, it should be postpone; the other utterance, any so on for etc. Sometimes, there is an exagerrated use of it and maybe such as shorthen it the explanation, maybe suggestion or something maybe.

Borrowing or code switching is the next category that most applied by presenters in the achievement and compensatory. Commonly, borrowing only used for address form, such as bang, pak or mbak. Also, it used for the foreign term for the target language like KKM or UN ,probably, because they could not find the appropriate term in the target language. While code switching was used probably because the presenter wanted to give a deeper explanation. The sociolinguists formulate that one of the functions of code switching is message qualification where the message is introduced in the target language and after that is explained in the native language.

Retrieval, the other sub-category achievement and compensatory, occured not because the presenters forgot the term and tried to remember about it but they employed just to take the time to think of the next utterances or to think about the correct pronunciation such as the partici...participation or to inc...increase the score there. This is actually not the actual function of retrieval.

One interesting fact that was found along the research is Word coinage, non linguistics means and circumlocution are seldom found in the class discussion for presenters . Probably, their level abilities in speaking L2 are quite good since most of the subject courses are conducted in L2. Therefore,word coinage is quite rarely discovered in this research. Then, non linguistics means mostly occured not to support the statement of the speakers but likely to help the speaker in gaining the time to think.

\footnotetext{
${ }^{7}$ Richard, Jack C.(1982). On Conversation. Singapore. Seameo Regional Language Centre.
} 
Next, approximation and foreignizing were not found in the class discussion. This probably arose because their levels of ability in utilizing L2 are quite good and their vocabularies are quite enough to fulfill their speaking. when they find difficulties in a certain word, they will probably employ the other strategies. Probably, since foreignizing is regarded as playing a joke, in the class discussion which was quite formal, the students were affraid of using it.

Meaning negotiation strategy, the sub category of interactional strategy, arose only to emphasize the presenters' explanation. the example of this strategy can be seen belows,

(11) while.. multiple choice also has ...aa....almost...the.. the lowest washback and authentcity. So you get it. It..it is called practical

(12) It can be the short dialoque, role play, discussion, debate or another language test.pak yus ,is it clear?

In some cases, they utilized it to make them sure with their utterances by confirming to their partners. For the other sub-categories, appeal for assistance occured in the class discussion by saying a statement like what is it? what we call it?. This utterances were used to ask the partner or even the audiences about the forgotten words. Yet, there is an interesting issue relating to appeal for assistance. It seems like presenters who employed this sub-category pretended that they asked for help. It can be seen like the utterances what we call it? eventhough this utterance is in a question intonation, it is not a kind of asking a favour. It can be proven by looking at to the pause time between she or he uttered the expression and the continuation of her or his statement. The time is only just in the short time constraint not the time for giving someone a chance to help.

\section{The reason of Students in employing communication strategies}

The audiences who asked the questions are nine persons. From the interview, it was discovered that the students asking question, the audience, made some efforts as well to make their statements became understandable. Therefore, they said that they used communication strategies.

There are some reasons why the students liked to apply communication strategies. First, the strategies utilized because they wanted to take time to think in arranging the question that is different with the question pattern of L1 or even in determining the choice of word diction. They said that because actually they had perpared the question that would be asked, yet they were difficult in choosing the appropriate words that were easier to be understood.

Second, beside gaining time to think, they also employed communication strategies to reduce the anxiety. Sometimes they employed paralinguitics strategy to reduce their nervousness. For example, by moving their hands or their eyes which actually did not support their statement exactly.

The last reason stated by the audience is because they wanted to keep the flow of the dialogue in order the dialogue wasnot stiff. They also said that because they did not want to cut out the dialog in co-incidentally.

While the presenters, as the information giver, the students giving the presentation or the answer should prepared prior to the day of presentation. So, they tended to make many efforts in order the listeners understood with the topic being presented. 
From the interview, it was found that most of the interviewee, the students giving the presentation or answer, produced communication strategies because of some reasons. First, the presenters employed the communcation strategies because they wanted to take time to think as well. Since they were the presenter who provided the information, they thought they had to master the lesson discussed. Therefore, they had to be carefull in giving their explanation to the listeners in order the listener understood with what they had explained. Thus, to made the kind of discussion and the topic being understood by the listeners, they applied some communication strategies.

Second, they used the strategies because they wanted to reduce the nervousness and the anxiety in the underpressure situation. In doing this strategy, they used fillers and sometimes mime or gesture like moving their hands which were not to support their sentence but merely to reduce the anxiety

The last reason is they felt that sometimes they indoubted with what they had expressed, so doing a kind of appeal for help made them more comfortable in giving their explanations.

Commonly, the presenters viewed the way they used communication strategies as to keep the communication open in the classroom discussion because they wanted the audience or the listener understood with what they had explained , as a result, they tried harder to make their communication became comprehensible and understandable by employing communication strategy. While the audience who asked the question tended to make the communication flowing smoothly and avoided the akward situations.

\section{Conclusion}

Communication strategy plays siginificant roles in enhancing communication especially in english language teaching environments. Its usage could assist the learners to overcome the barriers that they faced during oral communication using the target language. This research discovered that the communication strategies employed in explaining presentation (presenter) and asking question (the audience), exactly for speaking in interaction class. This research also found out the reason in using communication strategies from presenter side, they made their best efforts in order the message can be sent to the audience while the audience gave the reason to avoid the stiff situations.

Communication strategies employed by the students in answering questions in class discussions are avoidance and reduction, Achievement and Compensatory strategy, stalling and time gaining strategy, self monitoring, and interactional. Yet, the most frequent applied is stalling and time gaining strategy which was applied fillers and gambits. This was used to obtain the time to think to arrange the understandable sentence.

Communication strategy employed by the students in asking questions in class discussions are avoidance and reduction, Achievement and Compensatory strategy, stalling and time gaining strategy, self monitoring, and interactional. Then, also stalling and time gaining strategy was mostly applied by the students. This strategy applied fillers or gambits which also gaining the times for arranging the questions and for clarifying their question.

Most reason of the students both the presenters and the audiences employing the communication strategies in the class discussions is to keep the communication running smoothly, to make the utterances become understandable by the listener and to reduce the nervouseness and anxiety. Particularly, the presenters employed the strategies because they had 
planned ahead what would be explained in the discussion so they had to explained carefully by gaining some times to think.

\section{References}

Arends, Richard I.(2012). Learning to Teach $\left(9^{e d}\right)$. New York: McGraw Hill.

Aliakbari, Mohammad and Nabi Karimi Allvar. (2009). Communication Strategies in the Written Medium: The Effect of Language Proficiency. Linguistics online 40,4/09.ISSN 16153014 . (http://www.linguistik-online, retrieved on July 2010)

Brown, H. Douglas. (2007). The principle of Language Teaching and Learning. New York: Pearson Education

Brett, Angela Gallagher. (2001(. Teaching Communication Strategies to Beginners. Language Learning Journal. No 24 page 53-61

Celce-Murcia et.al. (1995). Communicative Competence: A Pedagogically Motivated Model With Content Specifications. Issues in Applied Linguistics. Vol 6 no 2. ISSN 1050-4273. 5-35

Creswell, John W. (2009). Research Design, Qualitative, Quantitative and Mixed Method Approaches. Los Angeles: Sage Publication

Corder, S. Pit.(1983). Strategies of Communication. In C Faerch \& G Kasper (Eds) .Strategies in interlanguage communication (p15-19). London: Longman

Kalisa , Pasca . (2019). Communication Strategies in English Second Language Acquisition. Language Circle: Journal of Language and Literature 14 (1).p 83-101

Crooker, Graham and Craig Chaudron. (1991). Guideliness for Clasroom Language Teaching. In Murcia, Marianne Celce (ed). Teaching English As A Second or Foreign Language $2^{\text {nd }}$. Los Angeles: New Bury House

Ellis, Rod.(1985). Understanding Second Language Acquisition. Oxford: Oxfrod University Press

Faerch, Claus and Gabrielle Kasper (Eds).1983. Strategies in Interlanguage Communication. London: Longman

Faerch, Claus and Gabrielle Kasper (Eds).1983. Plans And Strategies in Foreign Language Communication. Strategies in interlanguage communication. (p20-60) London: Longman

Faucette, Priscilla. (2001). A pedagogical perspective on Communication Strategies Benefits of Taining and An Analysis of English Language Teaching Materials. Second Language Studies. $19(2)$, page $1-40$ 
Gay, L.R. Mills, Geoofrey E and Peter Airasian. (2009). Educational Research : Competencies for Analysis and Applications $\left(9^{\text {th }}\right)$. London: Pearson education

Green, et.al. (1992) . Developing Discussing Skill in The ESL Clasroom. in Richard, Jack C and Willy A Renandya .Methodology in language teaching: An Anthology of a Current Practice . London: Longman. 226-228

Hie Ting, Su and Grace L Y Phan. (2008). Adjusting Communcation Strategies to Language Proficiency. Prospect Journal, Vol 22 (4). http://www.ameprc.mq.edu.au/docs/ prospect journal/volume 22 no 4/TingandPhan.pdf.

Hedge, Tricia. (2000). Teaching and Learning in Language Classroom. New York: Oxford

Irwandi, Albert, and Nur Azmi Alwi. 2018. Building Teachers' Intercultural Communication Competence in the Digital Era. Proceeding in $3^{\text {rd }}$ International Conference on Education in Digital Era, September, 12-13, 2018.

Jorda, Maria Pilar Safont. (2010). Some Comments onThe Existing Typologies of Communication Strategies: It Effect on The Interpretation of Empirical Findings.Universitat Jaume-I. (http://www.uji.es/bin/publ/edicions/jfi2/comments.pdf , retrieved on july 2010)

Kauchak, Donald. P and Paul D. Eggen. (2007). Learning And Teaching Research Based Method $5^{\text {th }}$. New York. Pearson Education Inc.

Murcia, Marianne-celce (ed). (1991).Teaching English As a Second or Foreign Language. Los Angeles: New Bury House

Miles, M. B and Huberman, A. M .(1992). Qualitative Data Analysis. Resource Book About New Methods. Translated. By Tjeptjep Rohendi Rohidi. Jakarta: Univ Indonesia Press.

Patton, Quinn, M. (1990). Qualitaive Evaluation and Research Method $2^{\text {nd }}$ ed. Los Angeles: sage publication, Inc

Permana, Gusti Komang et.al. (2019). An Analysis of Communcation Strategies applied by English Study Program Students in Speaking for Presenting. Journal of English Education and Teacbing (JEET) Vol 3 (4): 494-505.

Pangaribuan, Dharma et.al.(2020). Communication Strategies Used by Teachers. Linguistics, English Education and Arts (LEEA) Journal, Vol 3 (2): 274-286.

Richard,Jack C and Willy A. Renandya. (1994). Methodology in Language Teaching : An Anthology of a Current Practice (ed). London: Longman.

Richard, Jack C and Richard Smith. (2002). Longman Dictionary of Language Teaching and Applied Linguitics. London: Longman. 
Richard, Jack C.(1982). On Conversation. Singapore. Seameo Regional Language Centre.

Riggenbach, Heidi and Anne Lazaraton. (1991). Promoting Oral Communication Skills. In Murcia, marianne-celce (ed). Teaching English As a Second or Foreign Language. Los Angeles: New Bury House.

Sudijono, Anas. (2012). An Introduction to Educational Evaluation. Jakarta: PT. Raja Grafindo Perkasa.

Yusparizal et.al. (2018). Communication strategies used by ELT students acros Genders. Humaniora. Vol. 6 number $1 ; 24-47$

Zaim, Muhammad. (1997). The Acqusition of Questions by Indonesia Adult Learners of English as A Foreign Language. University of Tasmania. Unpublished Disertation. 